\title{
THE CONDITION AND CHALLENGES OF COMMUNITY LEARNING CENTRE IN THE OIL PALM PLANTATIONS OF SARAWAK, MALAYSIA
}

\author{
Bemen Win-Keong Wong* \\ School of Humanities, Universiti Sains Malaysia \\ Faculty of Social Sciences and Humanities, Universiti Malaysia Sarawak \\ Suriati Ghazali \\ School of Humanities, Universiti Sains Malaysia \\ Nooriah Yusof \\ School of Humanities, Universiti Sains Malaysia
}

\begin{abstract}
Sarawak is facing the problem of labour shortage in its oil palm plantations. It is difficult to recruit Malaysians to work in the plantations and, therefore, hiring foreign workers has become one of the solutions. Since the number of Indonesian workers and children is increasing, the Indonesian Government has requested to set up Community Learning Centre (CLC) in plantations for the Indonesian children in Sarawak. This article aims to explore the existence of CLC and the challenges faced by its teachers. A qualitative study has been employed, and data was collected using face-to-face interviews and interviews via telephone and text messages. The face-to-face interviews were conducted before and after the Movement Control Order was implemented in Sarawak. The first 16 CLCs were set up in 2016, and the number increased to 63 in 2020. CLC uses the Indonesian teaching syllabus, and the subjects are taught by Indonesian teachers (Guru Pamong and Guru Bina). Up to June 2020, there were 114 Indonesian CLC teachers in the state. The constraints of the CLC in Sarawak include limited classrooms, low motivation of the students, and lack of teaching and learning equipment which affects the effectiveness of teaching and learning. On the bright side, the CLC has given an opportunity to the Indonesian children in oil palm plantations in Sarawak to have primary education. After graduating from CLC, they can continue their studies in a secondary school in Indonesia since the teaching syllabus in CLC is similar to the one used in Indonesia.
\end{abstract}

Keywords: Community learning centre, Indonesian workers, Oil palm plantation, Indonesian children

Received: 13 November 2020

Accepted: 27 September 2021

https://doi.org/10.33736/ijbs.4328.2021

\section{INTRODUCTION}

Malaysia palm oil industry plays a significant role in Malaysia's economy (Potter, 2015). Between 2011 and 2018, the average annual contribution of palm oil in Malaysia's GDP is RM39.49 billion

\footnotetext{
* Corresponding author: Bemen Win Keong Wong, School of Humanities, Department of Geography, Universiti Sains Malaysia, 11800 USM Penang. Telephone: +60134010733. Email: bemenwong@student.usm.my/wwkbemen@unimas.my
} 
(Hirschmann, 2020). In general, the Malaysian oil palm planted area has increased by 0.66 per cent between 2017 and 2018, with a total of 5.85 million hectares in 2018 (Sundram, 2019). In line with the trend, the total planted area in Sarawak has almost doubled between 2009 and 2017, with a total planted area of 1.55 million hectares in 2017 (Malaysian Palm Oil Board, 2018).

Sarawak is the largest state in Malaysia, with an area of 124,450 km2 and a total population of 2.8 million in 2019, the fourth largest state in terms of population (Department of Statistics Malaysia, 2020). However, Sarawak is having a problem recruiting locals to work in oil palm plantations. The Malaysian Palm Oil Board affirms this issue, and due to labour shortage, the oil palm industry in Sarawak is losing RM1 billion annually due to uncollected fresh fruit bunches (FFBs) (SOPPOA, 2017; Masiron, 2018). Thus, hiring foreign workers is one of the solutions to solve the problem of labour shortages.

Due to the proximity between Malaysia and Indonesia, the majority of the workers in the oil palm plantations in Sarawak are Indonesians (Raghu, 2014; Hall, 2011). As reported by the United Nations (2019), among the six regions in the world (Africa, Asia, Europe, Latin America and the Caribbean, Northern America, and Oceania), about 90 per cent of Indonesian migrants are in the Asian region. Among the Southeast Asian countries in 2019, 88.35 per cent of the Indonesian migrants were in Malaysia.

As a result of being heavily dependent on Indonesian workers, the number of Indonesian children in Sarawak has also increased over the years. Yu (2016) reports that as many as 30,000 Indonesian children are excluded from formal education in Sabah and Sarawak. As agreed by Lisa (2021), undocumented children are denied access to education in government schools in Malaysia.

The Indonesian Government tries to look after the welfare of their people in the host countries (Farida et al., 2019). Due to the high dependency on Indonesian workers, the Indonesian Government realises that they have the token to demand better services for their migrant workers. One of those demands is a school, or Community Learning Centre (CLC), for the children living in the plantations.

Upon mutual agreement between the Indonesian Government and the Sarawak State Government, CLCs are allowed to be set up by the plantation companies to provide primary education to the Indonesian children. However, studies which explore and explain the condition of CLCs in Sarawak, namely the commitment of the plantation companies in the provision of CLCs, the students, the teachers, and the challenges of teaching in the CLCs, are very limited and not widely available. Thus, this article seeks to explore the conditions under which an oil palm plantation has to set up a Community Learning Centre (CLC) in Sarawak, examine who are the CLC teachers and analyse the issues and challenges of CLC from the perspective of the teachers.

\section{LITERATURE REVIEW}

Sarawak is located in the North West region of Borneo Island. It became part of Malaysia in 1963 and is the largest state of Malaysia with an area of $124,450 \mathrm{~km} 2$ and a total population of 2.81 million in 2019 (Department of Statistics Malaysia, 2019). Within Sarawak, there are 12 administrative divisions and 31 districts (Table 1). 
Table 1: The Administrative Divisions and Districts of Sarawak

\begin{tabular}{cccc}
\hline \hline Divisions & Districts & Divisions & Districts \\
\hline Kuching & Kuching & Sibu & Sibu \\
& Bau & & Kanowit \\
& Lundu & & Selangau \\
Samarahan & Samarahan & Mukah & Mukah \\
& Asajaya & & Dalat \\
& Simunjan & & Matu \\
& & & Daro \\
& Serian & Tintulu & Bintulu \\
Serian & Tebedu & & Tatau \\
& Sri Aman & Sebauh \\
& Kubok Antu & Kapit \\
Sri Aman & & & Belaga \\
& Betong & Song \\
& Saratok & Miri & Bukit Mabong \\
& Pusa & & Miri \\
Ketong & Kabong & & Marudi \\
& Sarikei & Subis \\
& Meradong & Beluru \\
& Julau & Timbang & Limbang \\
& Pakan & & Lawas \\
& Sarikei & & \\
& & &
\end{tabular}

Source: The Official Portal of Sarawak Government (2019)

Table 2: The Number of Population in the Divisions of Sarawak 2010

\begin{tabular}{cccc}
\hline \hline Divisions of Sarawak & Malaysian ('000) & Non-Malaysian ('000) & $\begin{array}{c}\text { Percentage of Non- } \\
\text { Malaysian }\end{array}$ \\
\hline Kuching & 705.5 & 12.6 & $1.79 \%$ \\
Samarahan & 159.0 & 2.0 & $1.29 \%$ \\
Serian & 91.6 & 1.8 & $1.92 \%$ \\
Sri Aman & 66.8 & 0.6 & $0.01 \%$ \\
Betong & 108.2 & 0.8 & $0.74 \%$ \\
Sarikei & 118.8 & 2.4 & $2.04 \%$ \\
Sibu & 299.8 & 15.7 & $5.25 \%$ \\
Mukah & 80.1 & 6.5 & $8.18 \%$ \\
Bintulu & 219.5 & 32.8 & $14.59 \%$ \\
Kapit & 112.8 & 5.9 & $5.26 \%$ \\
Miri & 364.6 & 32.3 & $8.85 \%$ \\
Limbang & 86.6 & 3.2 & $3.68 \%$ \\
\hline \hline
\end{tabular}

Source: Department of Statistics Malaysia (2019)

Table 2 shows that the top three divisions, which have the highest number of non-Malaysian, is led by Bintulu $(32,826)$, then followed by Miri $(32,253)$ and Sibu $(15,745)$. However, the percentage of non-Malaysian in each division illustrates a different ranking, which is led by Bintulu (14.59\%), Miri (8.85\%) and Mukah (8.18\%). 
The number of Indonesian within the total number of non-Malaysian in each division of Sarawak is unknown. According to Jabatan Imigresen Malaysia (2021), female and male Indonesian workers are allowed to work in all sectors except for male Indonesian workers; they are not allowed to work in the manufacturing sector.

\subsection{Indonesian Migrants in Malaysia}

Most Indonesian migrants are living in Asia. Table 3 shows that approximately 90 per cent $(4,086,876)$ of the Indonesian migrants are in the Asian region. The second highest is the European region, which has about 4.15 per cent $(188,008)$, followed by 2.82 per cent $(128,025)$ in the Northern America region, 2.37 per cent $(107,240)$ in the Oceania region, 0.45 per cent $(20,520)$ in the Africa region and only 0.05 per cent $(2,323)$ in the Latin America and the Caribbean region.

Table 3: Indonesian Migrants by Regions in 2019

\begin{tabular}{cc}
\hline \hline Regions & Indonesian Migrant \\
\hline Africa & $20,520(0.45 \%)$ \\
Asia & $4,086,876(90 \%)$ \\
Europe & $188,008(4.15 \%)$ \\
Latin America and the Caribbean & $2,323(0.05 \%)$ \\
Northern America & $128,025(2.82 \%)$ \\
Oceania & $107,240(2.37 \%)$ \\
\hline \hline
\end{tabular}

Source: United Nations (2019)

Within the Asian region, the majority of Indonesian migrants are located in Southeast Asia. The most popular destination for Indonesian migrants in Southeast Asia is Malaysia. Table 4 shows that the percentage of Indonesian migrants in Malaysia has never been below 85 per cent among the Southeast Asian countries. The highest percentage, 90.93 per cent, was recorded in 2005. Although the percentage dropped to 88.35 per cent in 2019, Malaysia remains the most popular destination for Indonesian migrants within the Southeast Asian region.

Table 4: The Destinations of Indonesian Migrants

\begin{tabular}{cccc}
\hline \hline Year & Asia & Southeast Asia & Malaysia \\
\hline 1990 & $1,315,257$ & $287,178(21.83 \%)$ & $252,710(88 \%)$ \\
1995 & $1,614,403$ & $472,978(29.30 \%)$ & $421,423(89.10 \%)$ \\
2000 & $2,061,956$ & $799,483(38.77 \%)$ & $726,961(90.93 \%)$ \\
2005 & $2,420,817$ & $977,061(40.36 \%)$ & $863,998(88.43 \%)$ \\
2010 & $3,022,485$ & $1,120,114(37.06 \%)$ & $960,819(85.78 \%)$ \\
2015 & $3,660,785$ & $1,357,196(37.07 \%)$ & $1,171,677(86.33 \%)$ \\
2019 & $4,086,876$ & $1,386,693(33.93 \%)$ & $1,225,156(88.35 \%)$ \\
\hline \hline
\end{tabular}

Source: United Nations (2019)

Compared with other countries within the Southeast Asian region, Malaysia dominates the ranking with 1.23 million (88.35\%) Indonesian migrants (Table 5). Ranked in second place is Singapore, with only $138,338(9.98 \%)$ Indonesian migrants. The country with the lowest number is Cambodia, with only 111 Indonesian migrants, while Lao People Democratic Republic and Myanmar recorded no Indonesian migrants in 2019 (Table 5). 
Table 5: The Destinations of Indonesian Migrants in Southeast Asia 2019

\begin{tabular}{cc}
\hline \hline Countries & Indonesian Migrant \\
\hline Brunei & $6,639(0.48) \%$ \\
Cambodia & $111(0.01 \%)$ \\
Lao People Democratic Republic & 0 \\
Malaysia & $1,225,156(88.35 \%)$ \\
Myanmar & 0 \\
Philippines & $3,407(0.25 \%)$ \\
Singapore & $138,338(9.98 \%)$ \\
Thailand & $669(0.05 \%)$ \\
Timor-Leste & $4,126(0.30 \%)$ \\
Vietnam & $8,217(0.59 \%)$ \\
& \\
\hline \hline
\end{tabular}

Source: United Nations (2019)

\subsection{Workers in the Oil Palm Plantations}

Malaysia palm oil industry plays a significant role in Malaysia's economy (Potter, 2015). The Gross Domestic Product (GDP) contribution from palm oil was RM37.66 billion in 2018 (Hirschmann, 2020). In between 2011 to 2018, the average contribution to Malaysia's GDP was RM39.49 billion annually. In 2018, it was believed that palm oil had contributed approximately 38 per cent to the agricultural GDP and 2.8 per cent to the total GDP of Malaysia.

In general, the Malaysian oil palm planted area has increased by 0.66 per cent, a growth of 38,185 hectares, from 5.81 million hectares in 2017 to 5.85 million hectares in 2018 (Sundram, 2019). Similarly, oil palm plantations in Sarawak have proliferated in the last four decades. Sarawak's oil palm planted area has increased from 23,000 hectares in 1980 to 840,000 hectares in 2009. The total planted area has almost doubled between 2009 and 2017, at 1.55 million hectares (Malaysian Palm Oil Board, 2018).

Workers in the Sarawak oil palm plantations are mainly Indonesian. As asserted by Raghu (2014) and Hall (2011), about 80 per cent of the oil palm plantation workforce are Indonesians, and the majority of them are from Java, Sulawesi, Lombok, Sumbawa and Flores. Sanderson (2016) and Pye et al. (2012) describe that low wages, long working hours, and harsh environment had discouraged the locals from working in plantations. Although oil palm plantations required a lower labour unit than other crops, such as rubber, the industry still faces a shortage of workers. However, others argued that the oil palm industry is labour intensive, and the issue of acute labour shortage has caused substantial losses in daily operations (Abdullah et al., 2011; SOPPOA, 2020). Due to the rapid expansion of plantations, more and more workers are needed (Cramb \& Mccarthy, 2016).

The harsh environment and working conditions have limited the recruitment of locals and, therefore, the industry needs to heavily depend on Indonesian workers (Hugo, 2004). There are reasons why Malaysian employers like to employ migrant workers. Firstly, from the perspectives of employers, migrant workers are hardworking. Secondly, the salary of migrant workers is relatively lower than that of the locals, and the migrant workers are willing to work in harsh conditions (Devadason \& Chan, 2014). However, the implementation of minimum wage nationwide, and its increment since 2018, has directly increased the cost of hiring foreign workers (Ram, 2019; Tay, 2019). 


\subsection{Undocumented Migrant Children}

Not every migrant-receiving country has a policy that allows undocumented migrant children to go to school. Among the top five destinations (Migration Policy Institute, 2017) of international migrants (United States, Saudi Arabia, Germany, Russia and the United Kingdom), only the United States has a positive education policy on undocumented migrant children. As listed by the Washington Office of Superintendent of Public Instruction (2017), undocumented children and young adults have the same right to attend public primary and secondary schools as do the United States citizens and permanent residents. Like other children, undocumented students are obliged under state law to attend school until they reach a mandated age.

Among the top five countries, Saudi Arabia has the harshest immigration policy on children. Children of foreigners who reside illegally will be detained and deported with their parents (The Law Library of Congress, 2017). Germany does not have a general policy in enrolling undocumented immigrant children into national schools. Other than Bavaria, which required compulsory school attendance for children without secure residence status, other federal states of Germany just leave it to the schools to decide whether to admit undocumented children (Sinn et al., 2005). In Russia, undocumented children have limited access to education, health care, and social assistance (The Law Library of Congress, 2017). Similarly, the children of undocumented immigrants in the United Kingdom are denied access to formal education (Boffey, 2013).

In Southeast Asia, the arrangement for undocumented migrant children is slightly different. Thailand has faced labour shortage since the 1990s and has to rely on migrant workers to fill up the Thais unwanted dirty, dangerous and demanding jobs (Jones, 2014). The majority of the migrants in Thailand are from Cambodia, Laos and Myanmar (CLM migrants), and among them, about 80 per cent are from Myanmar (Bryant, 2005; Huguet \& Chamratrithirong, 2011; Nawarat, 2012). CLM undocumented migrants crossed the border along with their family members, such as spouses and children. In order to provide education to the migrant children, Migrant Learning Centres (MLC) in Thailand are concentrated in the Chiang Mai and Mae Sot cities run by local NGOs (Nawarat, 2012).

Undocumented migrant children have limited access to education. Bryant (2005) examines the issues of migrant children in Malaysia and Thailand, and asserts that these children have difficulties in accessing government health and education services. However, Sabah (Malaysia) has a different approach to the issue of education for migrant children. There are about 227 CLCs throughout Sabah, accommodating approximately 24,000 Indonesian students (Shaiddin, 2017). There is also an Indonesian School in Kota Kinabalu, Sabah, which was established in 2008 and later moved to a new permanent school building in 2013 (Daily Express, 2013).

With the increasing number of Indonesian migrants, especially children, there are limited studies exploring informal education issues for migrant children, particularly in Sarawak, Malaysia. In the international context, a study that focuses on the education of undocumented migrant children has been conducted in Thailand (Tuangratananon et al., 2019). Meanwhile, other studies examine the issues of the usage of preschool centres by the immigrant children in the United States and discover that children from immigrant families, such as Mexican, Asian and other Hispanic children, are less likely to use centre-based child care (Brandon, 2004). Immigrant children who do not go to the centre-based child care centre will face difficulty in enrolling into schools. Other scholars had analysed the impact of parents outward migration (Mexican and Indonesian) on their children back 
home and discovered that family separation has a negative impact on the education of the leftbehind children (Lu, 2014). As supported by Adele et al. (2004), children separated from migrant parents have a deep level of depression that affects their schooling.

On the other hand, some studies highlight the positive outcomes from outward migrant parents. For example, Arguillas and Williams (2010) report that migrant parents who send remittances back home more frequently, high volume of remittances and work overseas for long periods, their older children (19-21 years old) have a higher tendency to continue until college level. In line with that argument, Hines and Simpson (2019) find that migrant households which receive remittances are more likely to allocate funds and spend more on education-related expenses. Similarly, AmuedoDorantes and Pozo (2010) conclude that remittances from migrant parents increase their children's attendance in school.

In the Sarawak context, there are studies related to international migration. For instance, Eilenberg and Wadley (2009) explore the issues of cross-border labour migration between West Kalimantan (Indonesia) and Sarawak and perceive cross-border labour migration as a survival strategy. Meanwhile, Lumayag (2020) compares the migration regulation between East and West Malaysia, while Lindquist (2017) examines the roles of a broker in bringing Indonesian migrant workers into Malaysia, especially for the oil palm plantations. However, very few studies have explored the issues of CLCs in the oil palm plantations of Sarawak. As affirmed by the Universal Declaration of Human Rights under Article 26, everyone has the right to education, and it has to be free, at least at the elementary stage (United Nations, n.d.). UNESCO (2020) points out that out of the 7.1 million refugee children, more than half do not have access to quality education. Therefore, studies related to CLCs are essential to contribute to the current literature, especially in the context of Sarawak, Malaysia.

\section{METHODOLOGY}

Qualitative data was obtained to achieve the objectives of this study. Due to the Covid-19 Pandemic in Malaysia, the authors were not allowed to visit any oil palm plantations in Sarawak in person. Therefore, several data collection methods were used to collect data in this study. These include face-to-face semi-structured interviews (which was conducted before the Covid-19 Pandemic in Malaysia and after the national Movement Control Order), interviews through telephone calls and text messaging, and secondary analysis. Each session of the face-to-face interview had lasted for between two to three hours. The interview sessions through telephone calls lasted for less than 20 minutes each session, and it took several sessions to complete the whole process, depending on the availability of the interviewees. Lastly, text messaging with the interviewees has been carried out in days and up to weeks, depending on the speed of replying and the amount of data the interviewees gave. Questions asked in the interviews include the issues of labour shortage in oil palm plantations of Sarawak, information related to CLC, and the challenges of teaching in CLC.

\subsection{Sampling Method}

A purposive sampling method has been used in this study. In general, the participants of this study must have specific attributes related to the issue studied, namely teachers of CLC in Sarawak and the management staff of the oil palm plantations. Nevertheless, another attribute is that the 
participants must know the issues of CLC in the plantations of Sarawak. These attributes include individuals such as the Consulate General of the Republic of Indonesia in Kuching and the Coordinators of CLC in Sarawak.

The interviewees who have participated in this study are three Plantation Managers (Miri, Mukah and Bintulu), a Human Resource Manager (Miri), a Human Resource Executive (Miri), a Manager in the Department of Sustainability (Bintulu), seven CLC teachers (five from Miri and two from Mukah), the Consulate General of the Republic of Indonesia (Kuching), and two CLC Coordinators (Kuching).

On 16 August 2019, face-to-face interviews were carried out in Miri with a Plantation Manager, a Human Resource Manager, a Human Resource Executive, and a CLC teacher. On 24 June 2020, a face-to-face interview was conducted with the Consulate General of the Republic of Indonesia in Kuching, Mr Yonny Tri Prayitno. On 11 December 2020, a face-to-face interview was conducted with the two Coordinators of CLC in the Indonesian Consulate Building, Mr Lucky and Mr Gaguk.

\section{RESULTS AND DISCUSSION}

\subsection{Shortage of Workers}

Oil palm plantations in Sarawak are facing the problem of labour shortage. Mr J, a plantation manager in Miri, states that his plantation needs at least 30 Indonesian workers to fulfil the minimum production output (Mr J, personal communication, August 16, 2019). He also added that an additional 60 workers would be the ideal number to increase production. According to Mr Tony, a Human Resource Manager of an oil palm plantation in Miri, the problem of labour shortage is not only faced by an individual company but all the plantations in the whole State of Sarawak. No locals want to work in the plantation except at the management levels (Mr Tony, personal communication, August 16, 2019).

The number of Indonesian workers needed in every plantation varies from each other. Mr Tony needs an additional 800 Indonesian workers annually to distribute to all his plantations in Sarawak at the company level. There are two ways of recruiting Indonesian workers. One way is through a 'Tekong' (a recruitment agent in Indonesia), and another way is through his current workers.

Recruiting through the Indonesian 'Tekong' is the main option for Mr Tony's company. A reliable 'Tekong' with a good reputation is the key in the process of recruitment. According to Mr Tony, a 'Tekong' is a recruitment man or middle man in Indonesia who is able to identify and source for potential workers who want to work in Sarawak. Sarawak based management staff have to go to Indonesia to meet the 'Tekong' at least four times a year to facilitate the recruiting process. The representative will conduct a briefing session at a designated place previously arranged by the 'Tekong' with the potential workers. The main task of the management staff from Sarawak who attended the session is to brief, convince and answer the questions asked by the potential workers. The most popular questions are as follows:

1. Can I bring along my spouse? Any jobs for her?

2. How tall are the palm trees? 
3. Can I bring along my kid/children? Any school at the estate?

Mr Tony elaborated that different oil palm companies constantly offer jobs to the existing pool of potential workers. Therefore, the workers can choose to accept their preferred plantation, which meets their needs and requirement. For example, married workers would like their spouses to go along and work in the same plantation. Those who have experience working in the plantation industry will prefer short palm trees. Those who intend to bring along their children will ask about the school or CLC in the plantation. Thus, CLC is one of the components that can facilitate the process of recruitment.

\subsection{Community Learning Centre in Sarawak}

The Indonesian Government is concerned about the education of its migrant children. It all started in the 11th Joint Commission for Bilateral Cooperation (JCBC) between Malaysia and Indonesia in 2011 at Lombok when the Indonesian President proposed to build schools and CLCs for children of Indonesian workers in Malaysia (Lai, 2015). As reported by Yu (2016), the media of Indonesia estimated that there were approximately 51,000 Indonesian children in Sabah and Sarawak, and about 30,000 of them might not have access to formal education. In the recent report, the United Nations also urged host countries to integrate migrant children into formal education or school of the host countries (AFP News, 2018).

Although the Indonesian Government requests for Indonesian Schools in Sarawak, the Ministry of Welfare, Women and Family Development makes a clear statement that Indonesian School is not allowed in Sarawak. However, the ministry allows CLC to be set up in oil palm plantations for the Indonesian migrant children aged seven to twelve years old.

Table 6: The CLCs and Students in Sarawak

\begin{tabular}{ccc}
\hline \hline Year & Number of CLCs in Sarawak & Number of students \\
\hline 2016 & 16 & 674 \\
2017 & 16 & 826 \\
2018 & 54 & 1474 \\
2019 & 63 & 1870 \\
2020 & 63 & 1956 \\
\hline \hline
\end{tabular}

Source: Unpublished data

The first 16 CLCs were established in 2016 in the plantations of Sarawak (Miri and Bintulu), which accommodated a total of 674 students (Table 6). In 2017, there was no additional CLC, but the number of students has increased to 826. A sharp increase was recorded in 2018 with an addition of 38 CLCs, an increment of about 70 per cent, with a total of 54 CLCs in the state. The number of students also increased to 1474, an approximately 44 per cent increment from the previous figure. The total number of CLCs in 2019 is 63, with 1,870 Indonesian students. (Y. T. Prayitno, personal communication, June 24, 2020). Up to December 2020, the number of CLCs is still 63, accommodating 1,956 Indonesian students in the plantations of Sarawak.

Not all plantations companies in Sarawak are required to provide CLC in their plantation. As described by Mr Tommy (nickname), who works at the managerial level in one of the plantations 
in Miri, the company only has to notify the office of the Consulate General of Indonesia in Kuching when the particular plantation has more than 30 children between 7 to 12 years old (Tommy, personal communication, August 16, 2019). However, the Coordinator of CLC in Sarawak disagrees with that statement. According to Mr Gaguk, if the plantation has less than 30 children but has the intention of setting up a CLC, the plantation owner is most welcome to do so, and the General Consulate office is more than happy to support the initiative (Gaguk, personal communication, December 11, 2020).

Most of the CLCs in Sarawak operate from Monday to Saturday, from 7.30 am to $11.30 \mathrm{am}$. There are nine subjects taught in the CLCs, namely Bahasa Indonesia, English, Pendidikan Agama Islam (PAI), Pendidikan Budi Pekerti, Pendidikan Kewarganegaraan (PKn), Pendidikan Jasmani (Penjas), Mathematics, Ilmu Pengetahuan Alam (IPA), Ilmu Pengetahuan Sosial (IPS), and Seni Budaya dan Ketrampilan. In addition, some CLCs have day care facility for the workers to send their children (6 years old and below) during working hours.

\subsection{International Sustainability and Carbon Certification (ISCC) 202}

The amended European Union (E.U.) biofuel legislation requires leading businesses to purchase sustainable certified palm oil (Novelli, 2016). Subsequently, in 2018, the European Parliament voted to ban palm oil for the production of biofuels in the E.U. to stop deforestation, particularly in the world's top 2 palm oil-producing countries, Indonesia and Malaysia (Klepper, 2018). In order to ensure deforestation-free supply chains, ISCC becomes one of the tools as a safeguard against deforestation.

ISCC is a globally applicable sustainability certification system that provides sustainability solutions for fully traceable and deforestation supply chains. It is oriented to reduce greenhouse gas emissions, ensure sustainable land use, protect natural biospheres, and safeguard social sustainability (International Sustainability and Carbon Certification, 2016). Plantations with ISCC have to comply with six principles, and Principle 4 is related to children's education on site.

Principle 4 is called Compliance with Human, Labour and Land Rights. Under Principle 4.1.6, "All children of primary schooling age (according to national legislation) living on the farm or plantation must have access to primary school education, either through provided transport to a public primary school or through adequate on-site schooling" (International Sustainability and Carbon Certification, 2016, pp. 36). Therefore, plantations that comply with ISCC must set up a CLC in their plantation in order to fulfil Principle 4.1.6 requirement.

\subsection{The Teacher of CLCs in Sarawak}

In general, there are two categories of teachers in the CLCs of Sarawak, Guru Pamong and Guru Bina. According to Mr Yonny (Y. T. Prayitno, personal communication, June 24, 2020), there is a minimum requirement to fulfil in order to become a Guru Pamong. First, they must have at least finished secondary school. According to Konsulat Jenderal Republic Indonesia di Kuching (2019), Guru Pamong must have at least SMK (Sekolah Menengah Kejuruan)/ SMA (Sekolah Menengah Atas) academic qualification. SMK is a vocational upper-secondary school, while SMA in Indonesia is equivalent to STPM in Malaysia. Although the owner of plantations recruits this category of teacher, the Ministry of Education Indonesia has to approve it before the recruitment 
can take place. Further explained by one of the CLC Coordinators in Sarawak, Mr Lucky, Guru Pamong is a conversion from an existing plantation worker (who meets the minimum qualification) to a teacher (Lucky, personal communication, December 11, 2020). Thus, Guru Pamong still receives the same salary from the plantation company as before, and the only thing that changes is the job description, from a plantation worker to a teacher of CLC.

On the other hand, Guru Bina is a teacher who possesses teaching qualifications and is qualified to teach in government schools in Indonesia. By referring to one Guru Bina in Balingian (Mukah, Sarawak), whom I have interviewed, he has a total of eight years of teaching experience in schools located in West Java, Indonesia. Guru Bina is recruited and assigned by the Ministry of Education of Indonesia to the CLCs in Sarawak, and the ministry pays their salary.

Guru Pamong and Guru Bina have different roles and responsibilities in the CLC of Sarawak. Guru Pamong is responsible for building characteristics, whereas Guru Bina is responsible for building the intellectuality of the students (Y. T. Prayitno, personal communication, June 24, 2020).

Table 7: The CLC Teachers in Sarawak

\begin{tabular}{|c|c|c|c|}
\hline \multirow[t]{2}{*}{ Categories of Teacher } & \multicolumn{2}{|c|}{ Number of Teachers (June 2020) } & \multirow[t]{2}{*}{ Total } \\
\hline & Male & Female & \\
\hline Guru Bina & 18 & 5 & 23 \\
\hline Guru Pamong & 19 & 72 & 91 \\
\hline Total & 37 & 77 & 114 \\
\hline
\end{tabular}

Source: Unpublished data

Table 7 illustrates the total number of CLC teachers in Sarawak. There are 114 Indonesian CLC teachers in Sarawak up to June 2020 that comprises 37 males and 77 females. Of the total of 114 CLC teachers, 91 are Guru Pamong, and 23 are Guru Bina. For Guru Bina, 18 (78\%) are males, and only $5(22 \%)$ are females. However, the category of Guru Pamong shows a different composition. The male teachers only comprised 19 (21\%), but the female teachers dominated with $72(79 \%)$.

Although Guru Pamong does not have the official teaching qualification, training programs have been organised from time to time to increase their teaching competency. For example, a training program was organised at the Sarawak Oil Palms Academy Training Centre, Lambir (Miri, Sarawak), in 2018 and was attended by 50 CLC teachers. Another training program was organised in a hotel in Bintulu, Sarawak, on 15-17 December 2019 and was followed by 30 Guru Bina and 18 Guru Pamong (Atdikbud Kuala Lumpur, 2018; 2019). Similar to the findings of Fatimah (2010), the teaching skills of a Guru Pamong is essential to enhance the effectiveness of teaching and learning in a classroom.

\subsection{The Students and the Classrooms}

Table 8 shows the breakdown of the four CLCs in terms of the number of teachers, students and number of plantations that shared a CLC. One CLC is located in Balingian, and the other three are in Miri. 
Table 8: The Profile of CLCs in Balingian and Miri

\begin{tabular}{ccccc}
\hline \hline & Balingian (Mukah) & Miri (T) & Miri (A) & Miri (B) \\
\hline Teachers & Pamong: 2 & Pamong: 2 & Pamong: 3 & Pamong: 2 \\
& Bina: 1 & & & 30 \\
Students & 42 & 24 & 3 & 34 \\
Sharing by plantation & 5 & 2 & 1 \\
\hline \hline
\end{tabular}

Most of the CLCs do not have the privilege to have classrooms according to the year of study due to the uneven distribution of the students. For instance, a CLC in Balingian, Mukah, has 42 students, but the majority of the students are from Year 1 (Table 9).

Table 9: The Students of CLCs

\begin{tabular}{ccccc}
\hline \hline Year of Study & Balingian (Mukah) & Miri (T) & Miri (A) & Miri (B) \\
\hline 1 & 19 & 4 & 2 & 8 \\
2 & 9 & 5 & 3 & 6 \\
3 & 2 & 4 & 10 & 7 \\
4 & 6 & 2 & 6 & 5 \\
5 & 4 & 4 & 3 & 8 \\
6 & 2 & 5 & 6 & 0 \\
Total students & $\mathbf{4 2}$ & $\mathbf{2 4}$ & $\mathbf{3 0}$ & $\mathbf{3 4}$ \\
\hline \hline
\end{tabular}

In the case of the CLC in Balingian, Year 1 can have its classroom whereby Year 2 and 3 have to share a classroom, and Year 4 until Year 6 share another classroom. Similarly, the Miri (T) CLC has only two classrooms, and it has to be shared by 24 students from six different grades. Therefore, the students have to be divided into two classrooms accordingly. Another reason for sharing classrooms by multi-grade students is due to the limited number of teachers available.

\subsection{Post-elementary Education}

The students and their parents have to make a crucial decision after completing their studies at CLC. After graduating from the elementary level in CLC, parents have to decide whether to allow their children to continue study at Sekolah Menengah Pertama (SMP) in Indonesia, which is equivalent to a secondary school in Malaysia or stop schooling altogether.

If the children are going to continue their study at the SMP level, there is only one way to do so, which is to send their children back to Indonesia (the village where they come from). However, sending their child back home alone is not feasible for both parents who are still working in the plantation in Sarawak. Therefore, there is an additional option for this group of students. As elaborated by one of the Coordinators of CLC in Sarawak, these students who are between 13-15 years old can continue their Sekolah Menengah Pertama (SMP) education at the same CLC in Sarawak, with the condition of the existing teachers can teach in that level (Gaguk, personal communication, December 11, 2020). As further explained by Mr Lucky, there is a total of 99 SMP students in the CLC of Sarawak up to December 2020 (Lucky, personal communication, December 11, 2020). 


\subsection{The Challenges of the Teachers}

One of the teachers in the CLC of Balingian, Mukah, Teacher B1, has teaching experience in Indonesia and Sabah before moving to Sarawak. He is a 32 years old male Guru Bina with a Master's Degree from one of Indonesia's universities. He was a teacher in a secondary school in West Java from 2010 to 2012 before being assigned by the Ministry of Education Indonesia to teach in a CLC in Tawau, Sabah, from 2012 to 2016. In between 2017 to 2019, he has returned to Indonesia and taught in a secondary school in West Java again. Since 2019, he has been teaching in a CLC in Balingian, Mukah, until now. He is married in Indonesia, and his wife is an Indonesian. His wife and his 4-year old child are with him in the palm oil plantation too.

The study identifies several challenges faced by the teachers of the CLCs. First is the students' motivation level. As explained by Teacher B1, the location and environment of the CLC and plantation did affect the students' motivation. This phenomenon is particularly glaring, especially when they are away from home and attend a new informal school in Sarawak. The lack of facilities at CLCs also affects the motivation of the students. Not only that, but the lack of facilities also undermines the process of teaching and learning. For example, a CLC in Miri has only a chair for the teacher in each of the two classrooms. Students have to sit on the floor and write on a low and long wooden table. The optimum capacity of each table is about four students. However, due to limited availability, the long tables were shared by eight students instead.

Another major challenge to teach in the CLC in Sarawak is the issue of multi-grade students. Due to the limited availability of classrooms in the CLC, students from different grades have to share the same classroom. One of the CLC teachers in Miri is concerned about this setup and feels that it would slow down the process of teaching and learning.

\section{CONCLUSIONS}

The provision of CLCs in oil palm plantations in Sarawak for Indonesian children started in 2016 with 16 CLCs and enrolled 674 students. In 2020, the number of CLCs had increased to 63 and can now accommodate a total of 1,956 students in the whole Sarawak. There are 114 Indonesian teachers, Guru Bina and Guru Pamong, teaching in the CLCs in Sarawak.

In general, Guru Pamong is recruited by the plantation owner, while Guru Bina is recruited by the Ministry of Education Indonesia. The rule of thumb is every CLC must have at least a Guru Pamong. Due to the limited number of Guru Bina available in the state, not every CLC has a Guru Bina on site. Although Guru Pamong does not have the official teaching qualification, training programs have been organised from time to time to increase their teaching competency.

There are three reasons why the plantation companies set up CLC in their plantations. First, it is to attract Indonesian workers. Since labour shortage is a big problem for all the oil palm plantations in Sarawak, CLCs could become one of the components to attract workers, particularly those with children. The establishment of a CLC in the plantations is also seen as 'standing out' and enables the company to stand out among the other competitors in the recruitment process. Second, plantations that complied with ISCC 202 have to provide education to the children of the workers. Thus, CLC is one of the ways to fulfil the requirement of Principle 4.1.6 (International Sustainability and Carbon Certification, 2016). Third, to build a good rapport with the Consulate 
General of the Republic of Indonesia in Kuching to facilitate the respective administration process (Mr Tony, personal communication, August 16, 2019).

Lastly, the main issues in the CLC of the respective plantations include the lack of teaching equipment, limited classrooms, lack of Guru Bina in Sarawak, and challenges to teach multi-grade students in the same classroom.

\section{ACKNOWLEDGEMENT}

Thanks to the suggestions and comments of three anonymous reviewers and Assoc. Prof. Dr Evan Lau, whose great job improves the quality of this paper. However, all the faults and deficiencies belong to the authors.

\section{REFERENCES}

Abdullah, R., Ismail, A., Khomeini, A., \& Rahman, A. (2011). Labour requirements in the Malaysian oil palm industry in 2010. Oil Palm Industry Economic Journal, 11(2), 1-12.

Adele, J., Sharpe, J., \& Sogren, M. (2004). Children's experiences of separation from parents as a consequence of migration. Caribbean Journal of Social Work, 3(1), 89-109.

AFP News. (2018, November 20). U.N. Urges More Efforts to Integrate Migrant Children in Schools. AFP. https://sg.news.yahoo.com/un-urges-more-efforts-integrate-migrant-childrenschools-231301843.html

Amuedo-Dorantes, C., \& Pozo, S. (2010). Accounting for remittance and migration effects on children's schooling. World Development, 38(12), 1747-1759. https://doi.org/10.1016/j.worlddev.2010.05.008

Arguillas, M. J. B., \& Williams, L. (2010). The impact of parents' overseas employment on educational outcomes of Filipino children. International Migration Review, 44(2), 300-319. https://doi.org/10.1111/j.1747-7379.2010.00807.x

Atdikbud Kuala Lumpur. (2018, March 18). Dubes Rusdi Kirana Resmikan 17 CLC Baru di Sarawak. http://atdikbudkl.org/2018/03/18/dubes-rusdi-kirana-resmikan-17-clc-baru-disarawak/

Atdikbud Kuala Lumpur. (2019, December 19). Pelatihan Peningkatan Mutu Pendidik CLC Sarawak. $\quad$ http://atdikbudkl.org/2019/12/16/pelatihan-peningkatan-mutu-pendidik-clcsarawak/

Boffey, D. (2013). Illegal Migrants' Children Denied Access to Education and Housing. The Guardian. https://www.theguardian.com/uk-news/2013/nov/09/illegal-migrant-childrendenied-access-education-housing

Brandon, P. D. (2004). The child care arrangements of preschool-age children in immigrant families in the United States. International Migration, 42(1), 65-87. https://doi.org/10.1111/j.0020-7985.2004.00274.x

Bryant, J. (2005). Children of international migrants in Indonesia, Thailand and the Philippines: A review of evidence and policies. (Innocenti Working Papers No. 2005-05). UNICEF, Innocenti Research Centre.

Cramb, R., \& Mccarthy, J. F. (2016). Characterising oil palm production in Indonesia and Malaysia. In R. Cramb, \& J. F. Mccarthy (Eds.), The oil palm complex: Smallholders, 
agribusiness and the state in Indonesia and Malaysia (pp. 27-77). Singapore: NUS Press.

Daily Express. (2013, December 23). K.K. Indonesian School gets its own Building. http://www.dailyexpress.com.my/news.cfm?NewsID=87538

Department of Statistics Malaysia. (2019). Statistics yearbook Sarawak 2018. Kuching: Jabatan Perangkaan Malaysia, Sarawak.

Department of Statistics Malaysia. (2020), Pocket Stats Quarter 12020. https://www.dosm.gov.my/v1/index.php?r=column/cone\&menu_id=ZmV

QWXNaUmVCdlJOREtrQnRSWUVxdz09

Devadason, E. S. \& Chan, W. M. (2014). Policies and laws regulating migrant workers in Malaysia: A critical appraisal. Journal of Contemporary Asia, 44(1), 1-15.

Eilenberg, M., \& Wadley, R. L. (2009). Borderland livelihood strategies: The socio-economic significance of ethnicity in cross-border labour migration, West Kalimantan, Indonesia. Asia Pacific Viewpoint. https://doi.org/10.1111/j.1467-8373.2009.01381.x

Farida, E., Rahayu, \& Wijaningsih, D. (2019). Politics and legal philosophy of Indonesian migrant worker protection: Case study in Malaysia. International Journal of Scientific and Technology Research, 8(11), 2002-2004.

Fatimah, S. (2010). Persepsi mahasiswa PPLK program studi pendidikan Bahasa Inggris FBS terhadap UNP terhadap tugas dan tanggung jawab guru pamong. Lingua Didaktika, 4(1), 5966.

Hall, D. (2011). Where the streets are paved with prawns: Crop booms and migration in Southeast Asia. Critical Asian Studies, 43(4), 507-530.

Hines, A. L., \& Simpson, N. B. (2019). Migration, remittances and human capital investment in Kenya. Economic Notes, 48(3), e12142. https://doi.org/10.1111/ecno.12142

Hirschmann, R. (2020). Gross Domestic Product (GDP) from the Palm Oil Industry in Malaysia from 2011 to 2018. Statista. https://www.statista.com/statistics/952715/malaysia-gdp-frompalm-oil-industry/\#statisticContainer.

Hugo, G. (2004). International labour migration in the Asia-Pacific region: Emerging trends and issues. In D. S. Massey, \& J. E. Taylor (Eds.), International migration: Prospects and policies in a global market (pp. 77-103). New York: Oxford University Press.

Huguet, J. W. \& Chamratrithirong, A. (2011). Thailand migration report 2011. Bangkok: IOM Thailand.

International Sustainability and Carbon Certification. (ISCC) (2016). ISCC 202 Sustainability Requirements. $\quad \mathrm{https}$.//www.iscc-system.org/wp-content/uploads/2017/02/ISCC_202_ Sustainability_Requirements_3.0.pdf

Jabatan Imigresen Malaysia. (2021). Pekerja Asing. Kementerian Dalam Negeri. https://www.imi.gov.my/portal2017/index.php/ms/pekerja-asing.html

Jones, M. E. (2014). Learning to live together through education in Thailand. Bangkok: Education Policy and Reform Unit, UNESCO Bangkok.

Konsulat Jenderal Republic Indonesia di Kuching. (2019). Community Learning Centre (CLC) Sarawak. https://kemlu.go.id/kuching/id/news/1344/community-learning-centre-clc-sarawak

Klepper, G. (2018, July 8). Winners and Losers from the E.U.'s Proposed Ban on Palm Oil. EcoBusiness. https://www.eco-business.com/opinion/winners-and-losers-from-the-eus-proposed -ban-on-palm-oil/

Lai, A. (2015, April 1). Jakarta School gets Green Light. The Star Online. https://www.thestar.com.my/metro/community/2015/04/01/jakarta-school-gets-green-lightindonesia-has-to-follow-local-rules-in-move-to-educate-workers-child/

Lindquist, J. (2017). Brokers, channels, infrastructure: Moving migrant labour in the Indonesian- 
Plantations of Sarawak, Malaysia.

Malaysian oil palm complex. Mobilities, 12(2), 213-226. https://doi.org/10.1080/17450101.2017.1292778

Lisa, S. (2021). Malaysian School Targets Undocumented Children. Deutsche Welle. https://www.dw.com/en/malaysian-school-targets-undocumented-children/a-15637233

Lu, Y. (2014). Parental migration and education of left-behind children: A comparison of two settings. Journal of Marriage and Family, 76(5), 1082-1098. https://doi.org/10.1111/jomf.12139

Lumayag, L. A. (2020). Foreign labour migration in Sarawak, East Malaysia. International Migration, 58(6), 195-209. https://doi.org/10.1111/imig.12707

Malaysian Palm Oil Board. (2018). Oil palm planted area 2017. http://bepi.mpob.gov.my/index.php/en/statistics/area/188-area-2017/856-oil-palm-plantedarea-as-at-dec-2017.html

Masiron, S. S. (2018, January 5). Taxing Time for Oil Palm Growers. The Edge Markets. http://bepi.mpob.gov.my/news/detail.php?id=24804

Migration Policy Institute. (2017). Top 25 Destinations International Migrants. https://www. migrationpolicy.org/programs/data-hub/charts/top-25-destinations-international-migrants

Nawarat, N. (2012). Thailand education policy for migrant children from Burma. Procedia-Social and Behavioural Sciences, 47, 956-961.

Novelli, E. (2016). Sustainability as a success factor for palm oil producers supplying the European vegetable oil markets. Oil Palm Industry Economic Journal, 16(1), 8-17.

Washington Office of Superintendent of Public Instruction. (2017). Immigrant Student Identification: Definitions and Procedures. https://www.k12.wa.us/sites/default/files/public/migrantbilingual/pubdocs/tbipguidelinesim migrant.pdf

Potter, L. (2015). Managing oil palm landscapes: A seven-country survey of the modern palm oil industry in Southeast Asia, Latin America and West Africa. Bogor Barat: Center for International Forestry Research.

Pye, O., Daud, R., Harmonot, Y., \& Tatat, S. (2012). Precarious lives: Transnational biographies of migrant oil palm workers. Asia Pacific Viewpoint, 53(3), 330-342.

Ram, B. S. (2019). Employers worried about minimum wage hike. New Straits Times. https://www.nst.com.my/news/nation/2019/12/550331/employers-worried-about-minimumwage-hike

Raghu, A. (2014). Labour crunch hurts Malaysian palm oil growers as Indonesians stay home. Reuters. https://www.reuters.com/article/us-palmoil-labour/labour-crunch-hurts-malaysianpalm-oil-growers-as-indonesians-stay-home-idUSBREA3Q0P320140427

Sanderson, S. (2016). Malaysian oil palm and Indonesian labour migration: A perspective from Sarawak. In R. Cramb \& J. F. McCarthy (Eds.), The oil palm complex: Smallholders, agribusiness and the state in Indonesia and Malaysia (pp. 378-408). Singapore: NUS Press.

Shaiddin, A. N. (2017, May 30). 227 CLC dengan 24,000 pelajar di Sabah. Utusan Borneo. https://www.pressreader.com/malaysia/utusan-borneo-sabah/20170530/281642485126113

Sinn, A., Kreienbrink, A., Loeffelholz, H. D., \& Wolf, M. (2005). Illegally resident third-country nationals in Germany: Policy approaches, profile and social situation. Nürnberg: Federal Office for Migration and Refugees.

SOPPOA. (2017). A century of growth. Sarawak Oil Palm Plantation Owners Association. http://soppoa.org.my/archives/industry-news/a-century-of-growth.php

SOPPOA. (2020). Palm oil industry in Sarawak reeling from acute workers shortage which has further deteriorated during the last 8 months of Movement Control Order. Sarawak Oil Palm 
Plantation Owners Association. http://soppoa.org.my/archives/highlights/palm-oil-industryin-sarawak-reeling-from-acute-workers-shortage-which-has-further-deteriorated-during-thelast-8-months-of-movement-control-order.php

Sundram, K. (2019). Annual report 2018. Selangor: Malaysian Palm Oil Council.

Tay, C. (2019). Minimum wage rise to add RM2.5b outflow annually by foreign workers, MEF warns. The Edge Markets.

The Law Library of Congress. (2017). Laws Concerning Children of Undocumented Migrants in Selected Countries. https://www.loc.gov/law/help/undocumented-migrants/undocumentedmigrant-children.pdf

Tuangratananon, T., Suphanchaimat, R., Julchoo, S., Sinam, P., \& Putthasri, W. (2019). Education policy for migrant children in Thailand and how it really happens: A case study of Ranong Province, Thailand. International Journal of Environmental Research and Public Health, 16(3), 1-16. https://doi.org/10.3390/ijerph16030430

UNESCO. (2020). What You Need to Know about the Right to Education. UNESCO. https://en.unesco.org/news/what-you-need-know-about-right-education

United Nations. (n.d.). Universal Declaration of Human Rights. United Nations. https://www.un.org/en/universal-declaration-human-rights/

United Nations. (2019). Population Division: International Migrant Stock 2019 [Dataset]. https://www.un.org/en/development/desa/population/migration/data/estimates2/data/UN_Mi grantStockTotal_2019.xlsx

Yu, J. (2016, January 13). Sarawak says yes to CLCs but not Sekolah Indonesia. The Star Online. https://www.thestar.com.my/news/nation/2016/01/13/sarawak-sekolah-indones ia-clc/ 